\title{
CCNE2 wt Allele
}

National Cancer Institute

\section{Source}

National Cancer Institute. CCNE2 wt Allele. NCI Thesaurus. Code C49527.

Human CCNE2 wild-type allele is located in the vicinity of $8 q 22.1$ and is approximately 15 kb in length. This allele, which encodes G1/S-specific cyclin-E2 protein, is involved in the regulation of the G1/S transition of the cell cycle. The expression of this allele peaks at the G1-S phase and has distinct tissue specificity. 